\title{
CHANGES IN ANATOMY AND ROOT CELL ULTRASTRUCTURE OF SOYBEAN GENOTYPES UNDER MANGANESE STRESS ${ }^{(1)}$
}

\author{
José Lavres Junior ${ }^{(2)}$, Eurípedes Malavolta ${ }^{(3 \dagger)}$, Neusa de Lima Nogueira ${ }^{(4)}$, \\ Milton Ferreira Moraes ${ }^{(5)}$, André Rodrigues Reis ${ }^{(6)}$, Mônica Lanzoni Rossi ${ }^{(3)}$ \& \\ Cleusa Pereira Cabral ${ }^{(2)}$
}

\begin{abstract}
SUMMARY
The deleterious effects of both Mn deficiency and excess on the development of plants have been evaluated with regard to aspects of shoot anatomy, ultrastructure and biochemistry, focusing mainly on the manifestation of visual symptoms. However, there is little information in the literature on changes in the root system in response to $\mathrm{Mn}$ supply. The objective of this study was to evaluate the effects of Mn doses $\left(0.5,2.0\right.$ and $\left.200.0 \mu \mathrm{mol} \mathrm{L}^{-1}\right)$ in a nutrient solution on the anatomy of leaves and roots of the Glycine $\max (\mathrm{L}$.) cultivars Santa Rosa, IAC-15 and IAC-Foscarin 31. Visual deficiency symptoms were first observed in Santa Rosa and IAC-15, which were also the only cultivars where Mn-toxicity symptoms were observed. Only in IAC-15, a high Mn supply led to root diameter thickening, but without alteration in cells of the bark, epidermis, exodermis and endodermis. The degree of disorganization of the xylem vessels, in particular the metaxylem, differed in the cultivars. Quantity and shape of the palisade parenchyma cells were influenced by both Mn deficiency and toxicity. A reduction in the number of chloroplasts was observed in the three Mn-deficient genotypes. The anatomical alterations in IAC-15 due to nutritional stress were greater, as expressed in extensive root cell cytoplasm disorganization and increased vacuolation at high Mn doses. The degree of changes in the anatomical and ultrastructural organization of roots and leaves of the soybean genotypes studied differed, suggesting the existence of tolerance mechanisms to different intensities of Mn deficiency or excess.
\end{abstract}

Index terms: apoplast, Glycine max, optical microscopy, root diameter.

(1) Recebido para publicação em julho de 2008 e aprovado em fevereiro de 2009.

(2) Pós-doutorando, Laboratório de Nutrição Mineral de Plantas, Centro de Energia Nuclear na Agricultura, Universidade de São Paulo - CENA/USP. Caixa Postal 96. Av. Centenário 303, CEP 13400-970 Piracicaba (SP). Bolsista FAPESP. E-mail: jjlavres@yahoo.com.br

${ }^{(3)}$ Professor Catedrátido do Centro de Energia Nuclear na Agricultura, CENA/USP. ${ }^{\dagger}$ In memoriam

(4) Professora de Centro de Energia Nuclear na Agricultura, CENA/USP. Laboratório de Histopatologia Vegetal e Biologia Estrutural de Plantas. Piracicaba (SP). Bolsista CNPq. E-mail: nogueira@cena.usp.br

${ }^{(5)}$ Doutorando do Programa de Pós-graduação em Energia Nuclear na Agricultura e no Ambiente do CENA/USP. Bolsista FAPESP. E-mail: moraesmf@yahoo.com.br

${ }^{(6)}$ Doutorando em Ciências, Waseda University, Department of Civil and Environmental Engineer, Shinjuku Ku, 3-4-1 Okubo, Tokyo 169-8555, Japan. E-mail: andrekun@gmail.com

(7) Bióloga do Laboratório de Histopatologia Vegetal e Biologia Estrutural de Plantas, CENA/USP. E-mail: monicalr@cena.usp.br

(8) Bióloga do Laboratório de Nutrição Mineral de Plantas, CENA/USP. E-mail: cpcabral@cena.usp.br 


\title{
RESUMO: ALTERAÇÕES ANATÔMICAS E ULTRAESTRUTURAIS EM GENÓTIPOS DE SOJA PELA DESORDEM NUTRICIONAL EM MANGANÊS
}

\begin{abstract}
Os efeitos negativos provocados não apenas pela deficiência mas também pela toxidez de Mn no desenvolvimento das plantas têm sido avaliados considerando-se os aspectos anatômicos, de ultraestrutura e bioquímicos da parte aérea particularmente, onde os sintomas visuais são manifestados. Entretanto, há escassez na literatura de informações que abordem o sistema radicular. Os objetivos do presente estudo foram avaliar os efeitos do fornecimento de doses de $\operatorname{Mn}\left(0,5,2,0\right.$ e 200,0 $\left.\mu \mathrm{mol} \mathrm{L}^{-1}\right)$, em solução nutritiva, na anatomia e ultraestrutura de folhas e de raizes dos cultivares de Glycine max (L.): Santa Rosa, IAC-15 e IAC-Foscarin 31. Os sintomas visuais de deficiência foram observados primeiramente em Santa Rosa e IAC-15, os únicos a exibirem sintomas de toxidez. As doses de Mn promoveram espessamento do diâmetro radicular somente em IAC-15, porém sem alteração nas células do córtex, da epiderme, exoderme e endoderme. Os cultivares mostraram distintos graus de organização dos vasos de xilema, particularmente nos elementos de metaxilema. O número e a conformação das células dos mesofilos paliçádicos foram alterados pelas condições de deficiência e toxidez. Houve redução na quantidade de cloroplastos, nos três genótipos, somente na condição de deficiência. O genótipo IAC-15 apresentou maiores alterações devido ao estresse nutricional, como separação do protoplasma da parede celular radicular e incremento de células vacuoladas na mais alta dose. Os genótipos apresentaram diferentes graus de alterações anatômicas e ultraestruturais das folhas e raizes, sugerindo a operação de mecanismos de tolerância à deficiência ou à toxidez de intensidade diversa.
\end{abstract}

Termos de indexação: apoplasto, diâmetro radicular, Glycine max, microscopia óptica.

\section{INTRODUCTION}

Plant species and genotypes within species can differ widely in their tolerance to excess Mn (Foy et al., 1988) or susceptibility to Mn deficiency (Graham, 1988) in the soil or other substrates in which they grow. These differences are often hereditary (Broadley \& White, 2005; Pittman, 2005).

The tolerance mechanisms to excess Mn have been ascribed to Mn oxidation in the roots, restricted root uptake and translocation of excess Mn to leaves, as well as uniform distribution in the tissues, greater internal tolerance and interaction with other elements (mainly $\mathrm{K}, \mathrm{Ca}, \mathrm{Mg}, \mathrm{Fe}$, and $\mathrm{Si}$ ) and defense mechanisms against oxygen reactive species, e.g., the activation of enzymes such as ascorbate peroxidase, catalase, $\mathrm{Mn}$-superoxide dismutase and glutathione peroxidase (Demirevska-Kepova et al., 2004; Morita et al., 2006). On the other hand, better internal utilization or lower requirement, greater $\mathrm{Mn}$ redistribution, increased absorption rate, exsudation of organic acids, acidification of the rhyzosphere and geometry of the root system have been cited as mainly responsible for lower susceptibility to Mn deficiency (Graham, 1988; Rengel, 1999).

The harmful effects of both deficient and excess Mn on many species have been studied, mainly considering the morphological and anatomical aspects of the shoot ultrastructure and biochemistry, where the symptoms are manifested, particularly in the leaves (Demirevska-Kepova et al., 2004; Papadakis et al., 2007a,b). However, there are few reports on changes in anatomy and root ultrastructure in response to variations in Mn supply (McQuattie \& Schier, 2000) or regarding the genotype effect (Santandrea et al., 1998a,b; Izaguirre-Mayoral \& Sinclair, 2005).

This study examines the anatomical changes of leaf mesophyll and root cortex, and ultrastructural changes in root cells of three soybean cultivars, considering the nutritional disorders caused by deficient and excess $\mathrm{Mn}$ in a nutrient solution.

\section{MATERIAL AND METHODS}

The experiment was carried out in a greenhouse of the Centro de Energia Nuclear na Agricultura, of the Universidade de São Paulo, in Piracicaba, São Paulo State, Brazil. The three soybean cultivars Santa Rosa (deficiency sensitive), IAC-15 (intermediate) and IAC-Foscarin 31 (toxicity tolerant) - of the species Glycine max (L.) Merrill were grown in a nutrient solution, from May 17 to June 27, 2006.

The seeds were germinated in a shallow tray containing vermiculite moistened with $10^{-4} \mathrm{~mol} \mathrm{~L}^{-1}$ $\mathrm{CaSO}_{4}$. When the plants reached a height of $5 \mathrm{~cm}$ (phenologic stage V1) they were transferred to individual pots (volume of $2.5 \mathrm{~L}$, diameter $15 \mathrm{~cm}$ ) 
containing 2.0 L nutrient solution. The solution of Johnson et al. (1957) was used, modified by Epstein $\&$ Bloom (2005), diluted to $1 / 5$ of the usual concentration, at an initial $\mathrm{pH}$ of $4.97 \pm 0.03$. Three days after transplanting the seedlings, the nutrient solutions with Mn concentrations of 0.5, 2.0 and $200.0 \mu \mathrm{mol} \mathrm{L}-1$ were added, with three replications.

The plants with the most visible symptoms of deficiency (grown in solution with $0.5 \mu \mathrm{mol} \mathrm{L}{ }^{-1} \mathrm{Mn}$ ) and of toxicity $\left(200.0 \mu \mathrm{mol} \mathrm{L} \mathrm{L}^{-1}\right)$ as well as the "healthiest" plants $\left(2.0 \mu \mathrm{mol} \mathrm{L}{ }^{-1}\right)$ - phenological stages V3 and V4 - were chosen for tissue collection. For this purpose, the upper leaves and around $10 \mathrm{~mm}$ of the tips of secondary roots with absorbent hairs were collected. Great care was taken to collect homogeneous material. The average diameters of the root cross-sections were obtained under an optical microscope and calculated using the Integrated System for Analysis of Roots and Soil Cover (Sistema Integrado para Análise de Raízes e Cobertura do Solo - SIARCS), version 3.0.

The leaf samples for electron transmission and optical microscopy were fixed in a modified Karnovsky solution: $2 \%$ glutaraldehyde, $2 \%$ paraformaldehyde and $5 \mathrm{mmol} \mathrm{L}^{-1}$ calcium chloride, buffered to $\mathrm{pH} 7.2$ with $0.1 \mathrm{~mol} \mathrm{~L}^{-1}$ sodium cacodylate, for $48 \mathrm{~h}$ at $4{ }^{\circ} \mathrm{C}$, washed in $0.1 \mathrm{~mol} \mathrm{~L}^{-1}$ sodium cacodylate $(3 \times 15 \mathrm{~min}$.) and post-fixed for $1 \mathrm{~h}$ in $1 \%$ osmium tetroxide. After washing the samples quickly a few times in $0.9 \%$ saline solution, they were block-stained with $2.5 \%$ uranyl acetate in water at $4{ }^{\circ} \mathrm{C}$ and then dehydrated gradually in acetone $(25,50,75,90$ and $100 \%)$ and embedded in Epon 812 resin (Luft, 1961). Ultrathin sections (60-90 nm) were placed on copper grids covered with colloid, contrasted with $2.5 \%$ aqueous uranyl acetate for 15 min followed by lead citrate solution for $8 \mathrm{~min}$, according to Reynolds (1963). The sections were then examined under a Zeiss EM-900 transmission electron microscope at an accelerating voltage of $50 \mathrm{kv}$ and $3000 \mathrm{X}$ magnification. For optical microscopy, semi-fine sections $(150 \mathrm{~nm})$ were placed on glass slides and stained with $1 \%$ toluidine blue in a $1 \%$ borax solution. The slides were covered with slips using Entelan and examined under a Zeiss Axioscop 40 HBO 50 A/C optical microscope.

The plants were harvested at the time of sampling (reproductive cycle between V3 and V4) and were later separated in upper leaves (blade and petiole) and roots. The material, duly identified, was placed in paper bags, dried in a forced-air oven at $65^{\circ} \mathrm{C}$ for $72 \mathrm{~h}$ and weighed on a precision scale. The Mn concentration was determined by atomic absorption spectrometry, according to the method described by Malavolta et al. (1997).

The experiment had a completely randomized block design; the treatments were arranged in a $3 \times 3$ factorial scheme (three Mn doses $\mathrm{x}$ three soybean cultivars), with three replications. The data were submitted to statistical analyses by the SAS System for Windows 6.11 statistical program (SAS, 1996). In cases where the F-test indicated significant differences of means for the Mn doses, the Tukey test was applied to compare the means of cultivars and doses $(p<0.05)$.

\section{RESULTS AND DISCUSSION}

Visual symptoms of Mn deficiency appeared 12 days after the start of the treatments in genotypes Santa Rosa and IAC-15, and after 15 days in IACFoscarin 31. Visual signs of toxicity to excess Mn in the nutritient solution, six days after addding the micronutrient to the solution $(200.0 \mu \mathrm{mol} \mathrm{L}-1)$ were only observed on the cultivars Santa Rosa and IAC15. No symptoms were observed on the roots. There were no visual symptoms of Fe deficiency in the cultivars caused by excess Mn in the solution either. The Mn concentrations in the leaf and root samples are shown in table 1.

The average root diameter of the three cultivars was quantified based on the root tip cross sections (Table 2). The root diameter of cultivar IAC-15 increased by 63 and $116 \%$ with the increase of $\mathrm{Mn}$ in the solution, at the lowest and the highest rate, respectively. This effect was not as evident for the other cultivars and did not translate into a more efficient $\mathrm{Mn}$ uptake, that is, a greater $\mathrm{V}_{\max }$ value and lower $\mathrm{K}_{\mathrm{m}}$ and $\mathrm{C}_{\text {mim }}$ values (Lavres Jr., 2007). The increased root diameter (root thickening) may have been caused by suberization and lignification of the

Table 1. Manganese concentration in the deficient leaf $\left(0.5 \mu \mathrm{mol} \mathrm{L}{ }^{-1} \mathrm{Mn}\right)$, "healthiest" leaf $\left(2.0 \mu \mathrm{mol} \mathrm{L}^{-1} \mathrm{Mn}\right)$ and excess Mn leaf $\left(200.0 \mu \mathrm{mol} \mathrm{L}^{-1} \mathrm{Mn}\right)$ and in the root of three soybean cultivars: Santa Rosa, IAC-15 and IACFoscarin 31 , as related to $M n$ rates of $0.5 ; 2.0$ and $200.0 \mu \mathrm{mol} \mathrm{L}^{-1}$ in the nutrient solution

\begin{tabular}{|c|c|c|c|}
\hline \multirow{2}{*}{ Mn rate } & \multicolumn{3}{|c|}{ Cultivars } \\
\hline & Santa Rosa & IAC - 15 & IAC-Foscarin 31 \\
\hline \multirow[t]{2}{*}{$\mu \mathrm{mol} \mathrm{L} \mathrm{L}^{-1}$} & \multicolumn{3}{|c|}{$-\mathrm{mg} \mathrm{kg}^{-1}$} \\
\hline & \multicolumn{3}{|c|}{ Leaves } \\
\hline 0.5 & $12.5 \mathrm{cA}$ & $8.6 \mathrm{cA}$ & $9.8 \mathrm{cA}$ \\
\hline 2.0 & $30.6 \mathrm{bA}$ & $25.9 \mathrm{bA}$ & $24.0 \mathrm{bA}$ \\
\hline \multirow[t]{2}{*}{200.0} & $786.3 \mathrm{aA}$ & $886.3 \mathrm{aA}$ & $744.3 \mathrm{aA}$ \\
\hline & \multicolumn{3}{|c|}{ Roots } \\
\hline 0.5 & $6.3 \mathrm{bB}$ & $11.0 \mathrm{cA}$ & $12.6 \mathrm{cA}$ \\
\hline 2.0 & $10.4 \mathrm{bB}$ & $16.3 \mathrm{bAB}$ & $20.3 \mathrm{bA}$ \\
\hline 200.0 & $379.4 \mathrm{aB}$ & $579.8 \mathrm{aA}$ & $546.1 \mathrm{aA}$ \\
\hline
\end{tabular}

Lower case letters in the same column and upper case letters in the same row do not differ significantly by the Tukey test $(\mathrm{p}<0.05)$. 
Table 2. Average diameters of root cross-sections of the three soybean cultivars Santa Rosa, IAC-15 and IAC-Foscarin 31, as related to rates of 0.5 ; 2.0 and $200.0 \mu \mathrm{mol} \mathrm{L}^{-1} \mathrm{Mn}$ in the nutrient solution

\begin{tabular}{|c|c|c|c|}
\hline \multirow{2}{*}{ Mn rate } & \multicolumn{3}{|c|}{ Cultivars } \\
\hline & Santa Rosa & IAC-15 & IAC-Foscarin 31 \\
\hline
\end{tabular}

\begin{tabular}{cccc}
\hline$\mu \mathrm{mol} \mathrm{L}^{-1}$ & \multicolumn{3}{c}{$\mathrm{mm}$} \\
\cline { 2 - 3 } 0.5 & 0.30 & 0.32 & 0.30 \\
2.0 & 0.29 & 0.52 & 0.32 \\
200.0 & 0.35 & 0.69 & 0.35 \\
\hline
\end{tabular}

cortex cells, reducing water and nutrient uptake (Fitter, 1996).

The treatment with a Mn dose of $0.5 \mu \mathrm{mol} \mathrm{L}-1$ caused disorganization of the xylem vessels (metaxylem and protoxylem) in the cultivars Santa
Rosa and IAC-15, indicating incomplete differentiation of these veins and of the cells of the vascular cylinder (Figure 1 IA and IIA), when compared with IACFoscarin 31 (Figure 1 IIIA) and the control treatment, $2.0 \mu \mathrm{mol} \mathrm{L}^{-1}$ (Figure $1 \mathrm{IB}$ and IIB). This can be associated with the initial appearance of deficiency symptoms in the younger leaflets. In the genotypes Santa Rosa and IAC-15, grown at the lowest Mn rate, the number of xylem vessels was greater than in IACFoscarin 31. Apparently there was no change in the cell differentiation of the cortex, epidermis, exodermis and endodermis. However in the control treatment $\left(2.0 \mu \mathrm{mol} \mathrm{L}^{-1}\right)$ the number of xylem vessels, particularly in the metaxylem, was higher in plants of IAC-Foscarin 31 than of IAC-15 and Santa Rosa.

At a Mn dose of $200.0 \mu \mathrm{mol} \mathrm{L}-1$, there was disorganization of the xylem vessels, mainly in the Santa Rosa cultivar, along with a larger number of metaxylem elements. In IAC-Foscarin 31, only protoxylem elements were observed, well-arranged transversally along the central cylinder - medulla
(I)
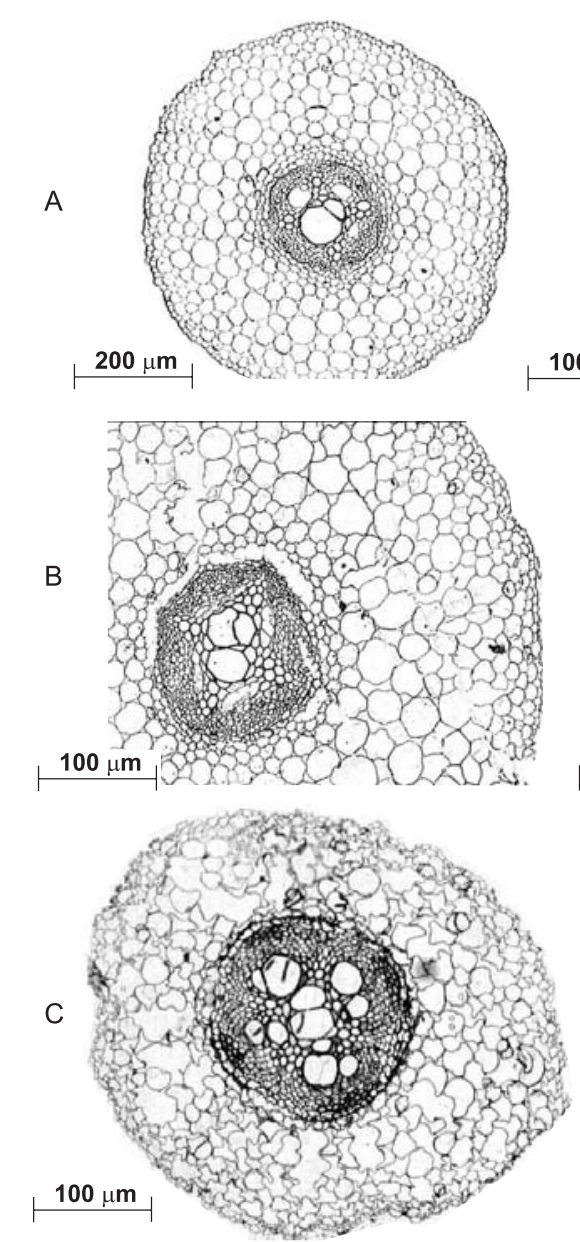

(II)
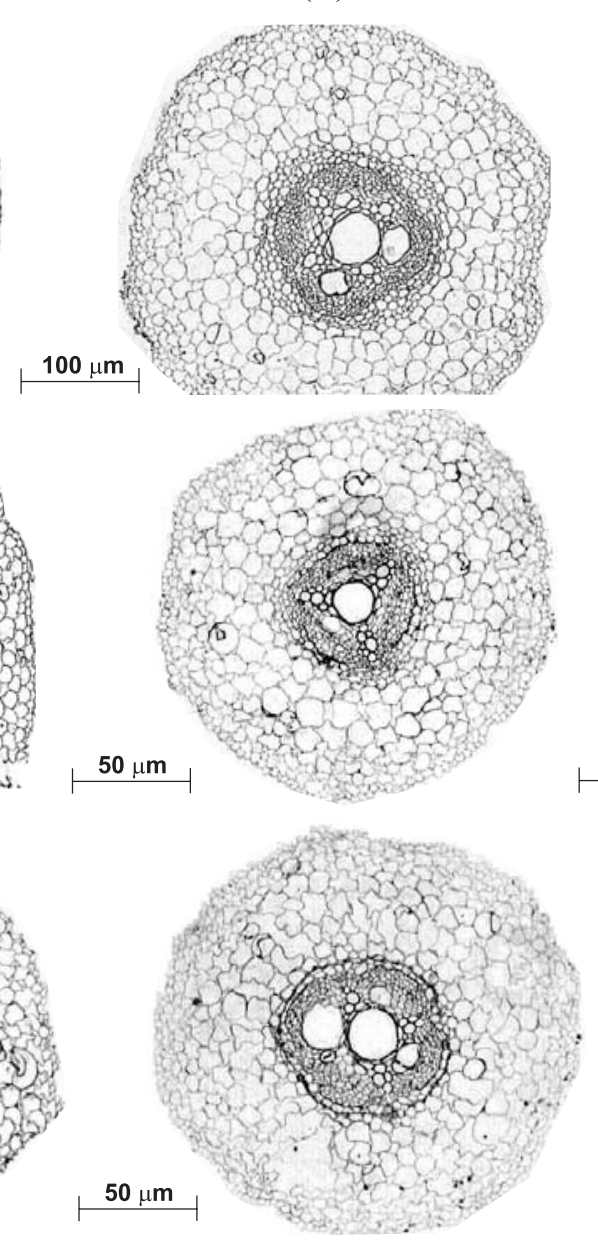

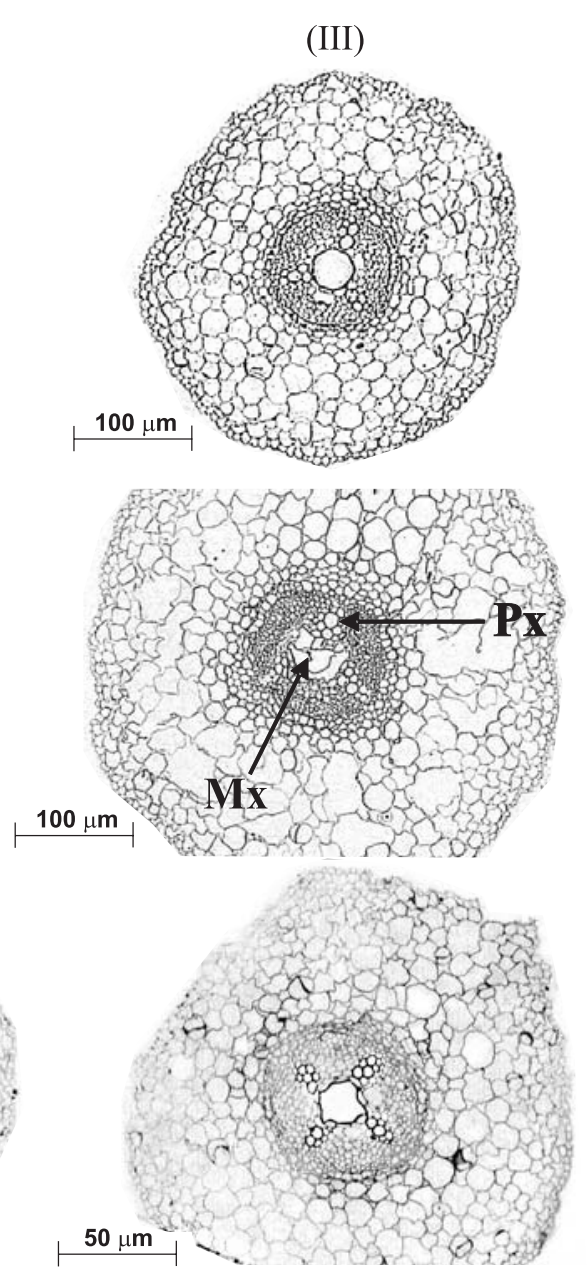

Figure 1. Root cross-sections $10 \mathrm{~mm}$ from the root tip of the three soybean cultivars Santa Rosa (I); IAC-15 (II) and IAC-Foscarin 31 (III), as related to Mn rates of $0.5 \mu \mathrm{mol} \mathrm{L}-1$ (A), $2.0 \mu \mathrm{mol} \mathrm{L}-1$ (B) and $200.0 \mu \mathrm{mol} \mathrm{L^{-1 }}$ (C), in nutrient solution. Anatomical features of the primary tissues: root cortex and bundle sheaths (xylem vessels). Xylem vessels detail (arrow) - protoxylem (Px) and metaxylem (Mx). 
(Figure 1 IIIC). For IAC-15 the presence of both a metaxylem (three veins) and protoxylem (three bundles containing an average of four veins each) were observed. The organization and order of the conducting veins, as well as the integrity of the cortical cells, play a fundamental role in nutrient absorption and transport processes. If on the one hand an organized arrangement of the conducting veins can allow a more efficient absorption (Rosolem et al., 2005) at low Mn availability, on the other hand, under excess $\mathrm{Mn}$ in the substrate, the maintenance of the cell integrity in the epidermis, exodermis, endodermis and cortex can confer greater root compartmentalization of $\mathrm{Mn}$, reducing the long-distance transport and finally diminishing the toxicity in the shoot (Lavres Jr. et al., 2008). In this context, the apoplast "compartment", or free space, apparently acts as an effective tolerance mechanism to micronutrient excess, notably in tolerant (hyperaccumulator) plants, as recently discussed by Lavres Jr. et al. (2008) and Führs et al. (2008).

However, Santandrea et al. (1998b) reported that the number of xylem elements (protoxylem and metaxylem) with lignified walls was higher in plants tolerant to excess $\mathrm{Mn}\left(5,000.0 \mathrm{mmol} \mathrm{L}^{-1}\right)$ than in the control plants $\left(100.0 \mathrm{mmol} \mathrm{L}^{-1}\right)$. They also found only protoxylem elements in the roots of the control group. With respect to lignification, it is known that Mn, along with $\mathrm{B}, \mathrm{Cu}$ and $\mathrm{Fe}$, is involved in the metabolism of phenol compounds and the biosynthesis of lignin. Lignification occurs by the activation of 3-deoxy-Darabino-heptulosonate-7-phosphate (DAHP) synthase [EC 2.5.1.54], in the secondary metabolism via shikimic acid. This phenomenon is more evident in the roots, where it represents a physical barrier against the entrance of pathogens. Manganese is a co-factor for the lyase of phenylalanine and ammonia, producing cinnamic acid and other phenols, besides being a co-factor of peroxidases (Huber \& Graham, 1999; Malavolta, 2006; Morita et al., 2006; Thompson \& Huber, 2007).

Observations by electron transmission microscopy of root cells of the three cultivars in the solution with $2.0 \mu \mathrm{mol} \mathrm{L}-1$ Mn (Figure 2 ) revealed more normally shaped cell walls and middle lamella than when grown at the lowest dose. The cells of the control treatment had normally shaped nuclei and cytoplasm filled with organelles (mitochondria), besides few vacuoles. The most significant ultrastructural changes were stated in IAC- 15 supplied with $200.0 \mu \mathrm{mol} \mathrm{L} \mathrm{L}^{-1} \mathrm{Mn}$. In this condition the protoplasm was separated from the root cell wall and the number of vacuolated cells increased (Figure 2 IIC). In IAC-Foscarin 31, under normal supply as well as excess $\mathrm{Mn}$ in the solution (Figures 2 IIIB and IIIC), inter-cellular spaces were observed, characterized as apoplast (or apparent free space). This possibly contributes to a greater accumulation and compartmentalization of $\mathrm{Mn}$ in the roots, which reduces the long-distance transport and confers greater tolerance to excess Mn (Lavres Jr. et al., 2008).
This phenomenon is in agreement with reports of Führs et al. (2008), who described that the leaf apoplast of cowpea (Vigna unguiculata L.), also a species of the Fabaceae family, is known for playing an important role in the tolerance to Mn excess/toxicity, due to the high peroxidase activity in this compartment.

The optical microscopic observations allowed the identification of structural differences in the mesophyll of the three cultivars (Figure 3). At the lowest Mn rate the cross sections of the leaf blades of the cultivars Santa Rosa and IAC-Foscarin 31 had several mesophyll cell layers, making it hard to distinguish the palisade from the spongy parenchyma (Figures 3 IA and IIIA). Both had broad and rounded cells, in agreement with reports of Papadakis et al. (2007a,b). However, these layers were clearly distinct in cultivar IAC-15 (Figure 3 IIA). There was a reduction in the number of chloroplasts, particularly in the palisade tissue, when compared to the control treatment $(2.0 \mu \mathrm{mol} \mathrm{L}-1 \mathrm{Mn})$. This effect was stronger in cultivar IAC-15. Weiland et al. (1975) reported significant differences in the chloroplast number per cell of the palisade parenchyma of soybean plants, varying from six chloroplasts per cell under deficient conditions to nine in well-supplied plants. The authors also noted this reduction in the cells of the spongy parenchyma. Papadakis et al. (2007a) also reported the negative effect of Mn deficiency on the reduction of chloroplast number in citrus leaves. In another study, the primary effect of a lack of Mn in pecan leaves (Carya illinoinensis (Wangenh.) C. Koch.) was a reduction in the number of chloroplasts in mesophyll cells, but the $\mathrm{Mn}$ content in the chloroplasts remained equal to those in the control treatment, without damage to the photosystem II (Henriques, 2004). It should be pointed out, however, that the number of chloroplasts can vary according to the portion of the cell shown in the cross sections. In other words, the possibility cannot be ruled out that a larger or smaller portion is represented at the moment of cutting the histological slides.

The palisade and spongy parenchymas of the three soybean cultivars grown in the solution with $2.0 \mu \mathrm{mol} \mathrm{L}{ }^{-1} \mathrm{Mn}$ were regularly distributed. Two cell layers could be identified in the palisade parenchyma of the upper leaf surface and a single layer of spongy cells on the abaxial face. The mesophyll cells had normal size and shape, with easily distinguishable chloroplasts distributed throughout the cells (Figure 3).

At the highest Mn dose, the chloroplasts of Santa Rosa and IAC-15 were concentrated in the lower part of the parenchyma cells (notably in the palisade tissue), resulting in a large area of cytoplasm and vacuole. The presence of a larger number of starch grains as well as the larger size of the plastoglobules in cultivar IAC-Foscarin 31, as reported by Lavres Jr. (2007), may have contributed to the smaller expansion of the vacuoles and cytoplasm, because of 
(I)
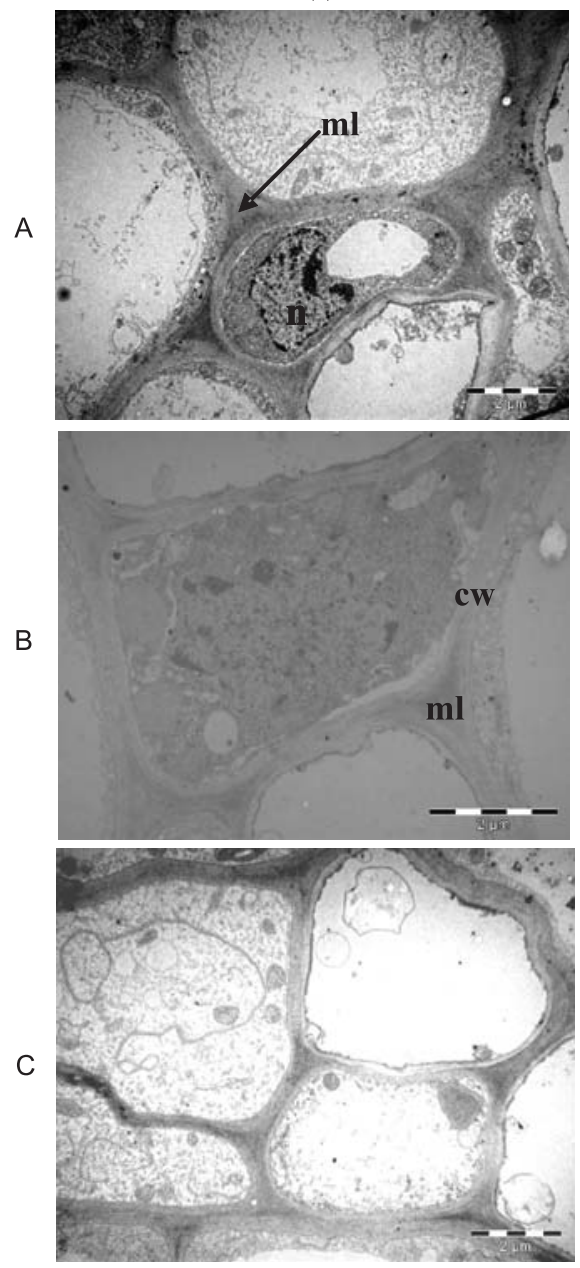

(II)
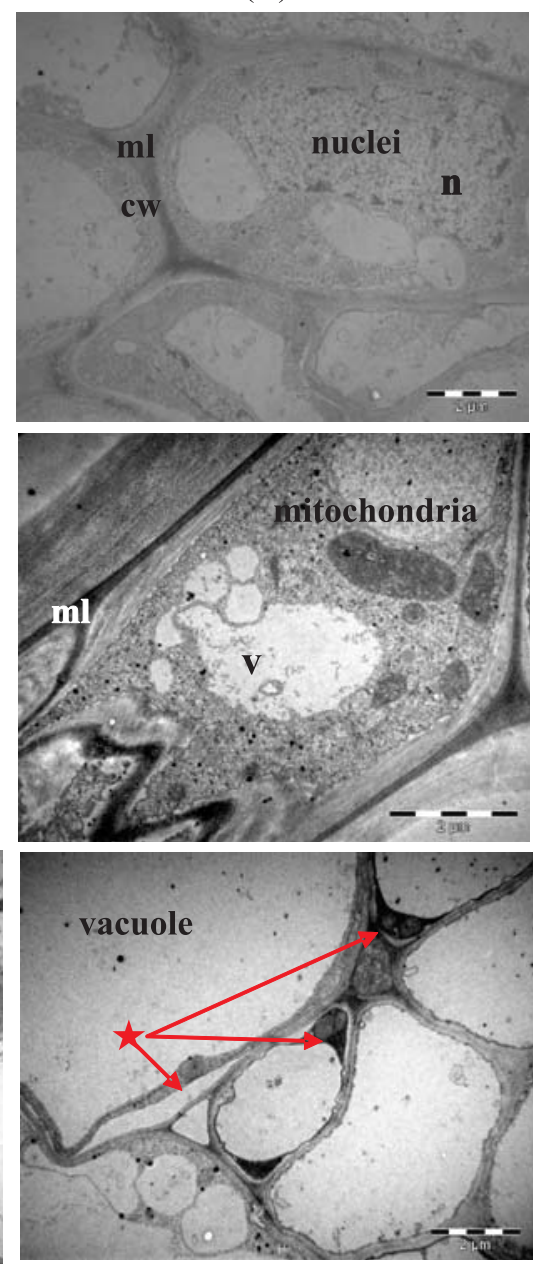

(III)
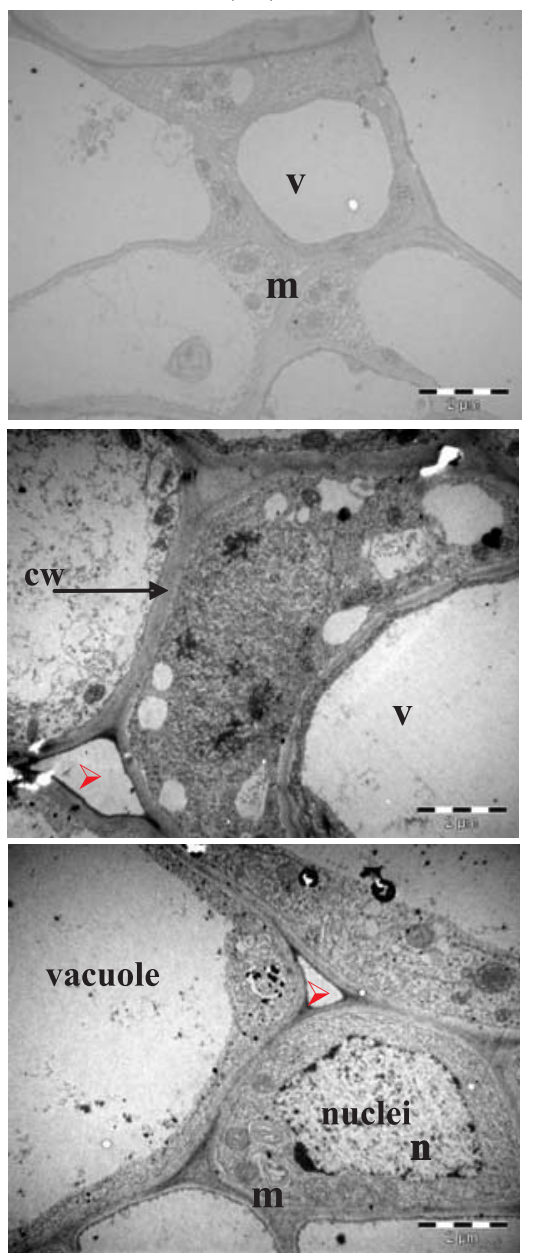

Figure 2. Transmission electron micrographs (x 3.000) showing root cell structure of soybean cultivars Santa Rosa (I), IAC-15 (II) and IAC-Foscarin 31 (III), as related to Mn rates of $0.5 \mu \mathrm{mol} \mathrm{L} \mathrm{L}^{-1}$ deficiency

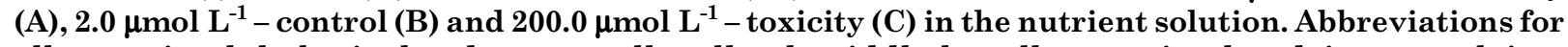
all parts in alphabetical order: $\mathrm{cw}$, cell wall; $\mathrm{ml}$, middle lamella; $\mathrm{m}$, mitochondria; $\mathbf{n}$, nuclei; $\mathrm{v}$, vacuole. [ $\star$ ] Detail of separated protoplast from cell wall in cultivar IAC-15, under Mn excess in the solution, and the apoplast (or apparent free space) [ $\gg$ ] in IAC-Foscarin 31, as related to Mn rates of 2.0 and $200.0 \mu \mathrm{mol} \mathrm{L}{ }^{-1}$. Scale bar: $2 \mathrm{~mm}$.

the increased size of the chloroplasts. Apparently there was no reduction in the number of chloroplasts in the three cultivars, unlike reported by Santandrea et al. (1998a), who observed a smaller number of these organelles in the mesophyll cells of Nicotiana tabacum (L.) maintained in solutions with 2,000 and $5,000 \mu \mathrm{mol} \mathrm{L}-1 \mathrm{Mn}$, doses higher than those tested in this study.

These results raise the following question: Can the smaller vacuole extension in IAC-Foscarin 31 have an influence on the accumulation of excess Mn, or do the cells of the palisade parenchyma (greater number of chloroplasts) have the capacity to "store" excess Mn? In a study of four forest species that are Mn hyperaccumulators - Gossia bidwillii, Virotia neurophylla, Macadamia integrifolia and Macadamia
tetraphylla-Fernando et al. (2006a,b) suggested that the accumulation of excess $\mathrm{Mn}$ in the leaves occurs by storage of the nutrient in the mesophyll cells of the palisade parenchyma (photosynthetically active tissue), as a behavior pattern in these accumulator plants, in contrast to $\mathrm{Cu}$ and $\mathrm{Ni}$, which are accumulated in the epidermis tissues (trichomas) and the vacuole (Arru et al., 2004; Broadhurst et al., 2004), and unlike $\mathrm{Zn}$ and $\mathrm{Cd}$, which are accumulated in the vacuoles of the spongy mesophyll cells and apoplast (Küpper et al., 1999; Di Toppi et al., 2005). The accumulation of Mn in the form of oxalate crystals is debatable (González \& Lynch, 1999).

According to Malavolta et al. (1997), the external manifestation of abnormality caused by toxicity to any element, essential or not, is the result of a chain of 
(I)

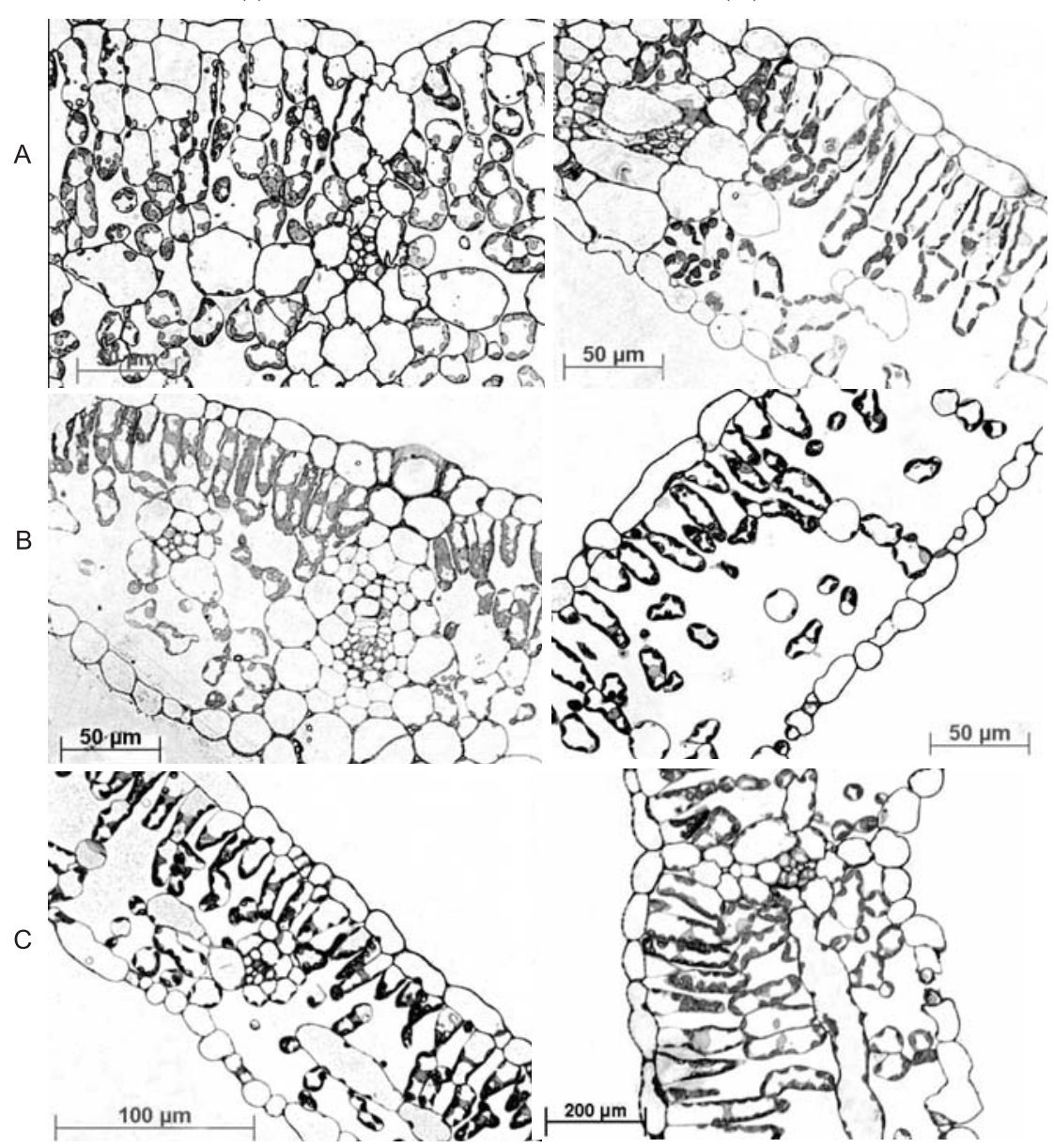

(III)
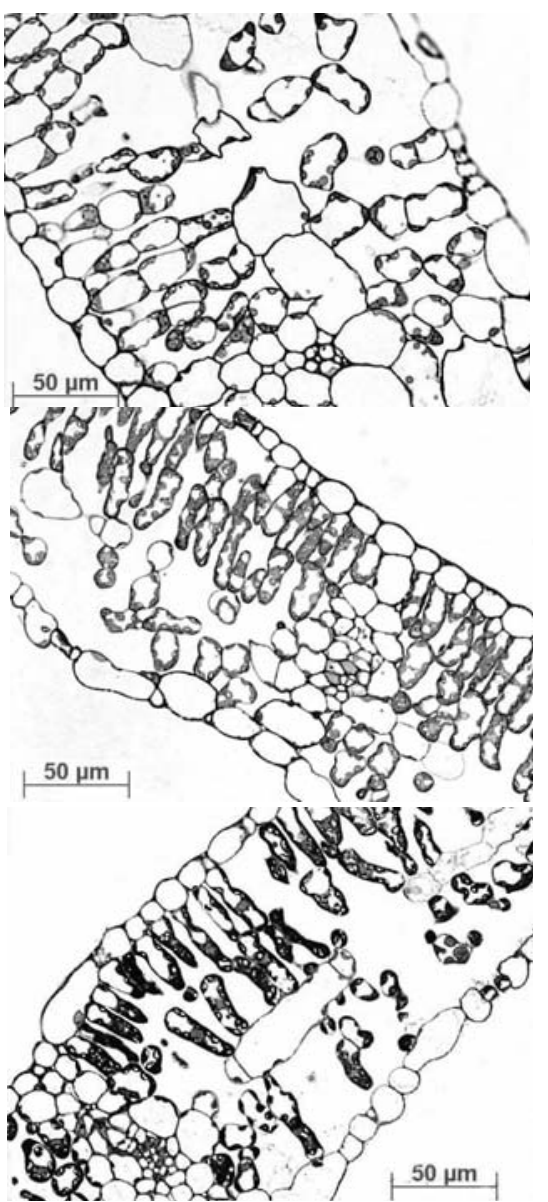

Figure 3. Leaf blade cross-sections of three soybean cultivars: Santa Rosa (I); IAC-15 (II) and IAC-Foscarin 31 (III), as related to $\mathrm{Mn}$ rates of $0.5 \mu \mathrm{mol} \mathrm{L}{ }^{-1}$ (A), $2.0 \mu \mathrm{mol} \mathrm{L} \mathrm{L}^{-1}$ (B) and $200.0 \mu \mathrm{mol} \mathrm{L} \mathrm{L}^{-1}$ (C), in the nutrient solution. Anatomical features of the leaf tissues: mesophyll cell of the palisade parenchyma (two cell layers in the upper leaf surface - as related to $\mathrm{Mn}$ rates of 2.0 and $200.0 \mu \mathrm{mol} \mathrm{L}{ }^{-1}$ ) and spongy parenchyma (a single layer of spongy cells in the abaxial face).

occurrences that starts with an alteration at the molecular level, continues with sub-cellular modification, which in turn leads to a cellular change that finally causes disorganization of the tissue - the symptom. The deficiency of any nutrient can also trigger this series of events, leading to the visual symptom.

According to the anatomical changes and timing of appearance of the symptoms of Mn deficiency and toxicity observed here, we can assume that there are various mechanisms that act together to maintain the biochemical processes and structural plant apparatuses, resulting in different degrees of tissue organization. We also suggest that Mn detoxification of cells by activation of the antioxidant defense system (enzymatic or not), binding of Mn to complexing agents in the root system (phytochelatins, metallothioneins and nicotianamine) and subsequent deposition of $\mathrm{Mn}$ in the apoplast, reduction of the long-distance transport of the metal-ligand complex, and finally, storage within the vacuoles (Yan et al., 2000; Bidwell et al., 2002; Ducic \& Polle, 2005), may all be more effective in the tolerant genotype, IAC-Foscarin 31.

\section{CONCLUSIONS}

1. The changes in root anatomical structures caused by Mn deficiency and excess, mainly in the metaxylem elements, differed among the three cultivars.

2. The number of chloroplasts in the mesophyll cells declined under Mn deficiency.

3. Anatomical and ultrastructural changes were more evident in cultivar IAC-15, particularly under excess $\mathrm{Mn}$, which may indicate a lower adaptive capacity to nutritional stress. 


\section{ACKNOWLEDGEMENTS}

We thank the Coordenação e Aperfeiçoamento de Pessoal de Nível Superior - CAPES and the Fundação de Amparo a Pesquisa do Estado de São Paulo FAPESP (Ref. Proc. 04/09411-4) for the financial and institutional support for this study; the National Council of Scientific and Technological Developmen $\mathrm{CNPq}$ for the research grant of E.Malavolta and N.L.Nogueira; FAPESP for the scholarship (master's degree, Ref. Proc. 06/54552-0) for A.R.Reis, the scholarship (doctorate) (Ref. Proc. 04/15897-7) for M.F.Moraes and the post-graduate scholarship (Ref. Proc. 07/58406-1) of J.Lavres-Jr. We also thank Dr. Elliot Watanabe Kitajima (NAP/MEPA, ESALQ-USP) for his assistance and allowing the use of the electron and optical microscopes.

\section{LITERATURE CITED}

ARRU, L.; ROGNONI, S.; BARONCINI, M.; BONATTI, P.M. \& PERATA, P. Copper localization in Cannabis sativa $\mathrm{L}$. grown in a cooper-rich solution. Euphytica, 140:33-38, 2004.

BIDWELL, S.D.; WOODROW, I.E.; BATIANOFF, G.N. \& SOMMER-KNUDSEN, J. Hyperaccumulation of manganese in the rainforest tree Austromystus bidwillii (Myrtaceae) from Queensland, Australia. Funct. Plant Biol., 29:899-905, 2002.

BROADHURST, C.L.; CHANEY, R.L.; ANGLE, J.S.; MAUGEL, T.K.; ERBE, E.F. \& MURPHY, C.A. Simultaneous hyperaccumulation of nickel, manganese and calcium in Alyssum leaf trichomes. Environ. Sci. Technol., 38:57975802,2004

BROADLEY, M.R. \& WHITE, P.J. Plant nutritional genomics. Oxford, Blackwell Publishing, 2005. 321p.

DEMIREVSKA-KEPOVA, K.; SIMOVA-STOILOVA, L.; STOYANOVA, Z.; HOLZER, R. \& FELLER, U. Biochemical changes in barley plants after excessive supply of cooper and manganese. Environ. Exper. Bot., 52:253-266, 2004.

DI TOPPI, L.S.; MUSETTI, R.; VATTUONE, Z.; PAWLIKSKOWRONSKA, B.; FOSSATI, F.; BERTOLI, L.; BADIANI, M. \& FAVALI, M.A. Cadmium distribution and effects on ultrastructure and chlorophyll status in photobionts and mycobionts of Xathoria parietina. Microsc. Res. Technol., 66:229-238, 2005.

DUCIC, T. \& POLLE, A. Transport and detoxification of manganese and copper in plants. Braz. J. Plant Physiol., 17:103-112, 2005.

EPSTEIN, E. \& BLOOM, A.J. Mineral nutrition of plants: Principles and perspectives. 2.ed. Sunderland, Sinauer, 2005. 400p.
FERNANDO, D.R.; BAKKAUS, E.J.; PERRIER, N.; BAKER, A.J.M.; WOODROW, I.E.; BATIANOFF, G.N. \& COLLINS, R.N. Manganese accumulation in the leaf mesophyll of four tree species: A PIXE/EDAX localization study. New Phytol., 171:751-758, 2006a.

FERNANDO, D.R.; BATIANOFF, G.N.; BAKER, A.J.M. \& WOODROW, I.E. In vivo localization of manganese in the hyperaccumulator Gossia bidwilli (Benth.) N. Snow \& Guymer (Myrtaceae) by cryo-SEM/EDAX. Plant Cell Environ., 29:1012-1020, 2006b.

FITTER, A. Characteristics and functions of root systems. In: WAISEL, Y.; ESHEL, A. \& KAFKAFI, U., eds. Plant roots: The ridden half. 2.ed. New York, Marcel Dekker, 1996. p.1-20.

FOY, C.D.; SCOTT, B.J. \& FISHER, J.A. Genetics and breeding of plant of manganese toxicity. In: GRAHAM, R.D.; HANNAM, R.J. \& UREN, N.C., eds. Manganese in soils and plants. Dordrecht, Kluwer Academic Publishers, 1988. p.293-307.

FÜHRS, H.; HARTWIG, M.; MOLINA, L.E.B.; HEINTZ, D.; van DORSSELAER, A.; BRAUN, H.P. \& HORST, W.J. Early manganese-toxicity response in Vigna unguiculata L. - a proteomic and transcriptomic study. Proteomics, 8:149-159, 2008.

GONZÁLEZ, A. \& LYNCH, J.P. Subcellular and tissue Mn compartmentalization in bean leaves under Mn toxicity. Aust. J. Plant Physiol., 26:811-822, 1999.

GRAHAM, R.D. Genotypic differences in tolerance to manganese deficiency. In: GRAHAM, R.D.; HANNAM, R.J. \& UREN, N.C., eds. Manganese in soils and plants. Dordrecht, Kluwer Academic Publishers, 1988. p.261-276.

HENRIQUES, F.S. Reduction in chloroplast number accounts for the decrease in the photosynthetic capacity of $\mathrm{Mn}$ deficient pecan leaves. Plant Sci., 166:1051-1055, 2004.

HUBER, D.M. \& GRAHAM, R.D. The role of nutrition in crop resistance and tolerance to diseases. In: RENGEL, Z., ed. Mineral nutrition of crops: Fundamental mechanisms and implications. New York, Food Products Press, 1999. p.169204.

IZAGUIRRE-MAYORAL, M.L. \& SINCLAIR, T.R. Soybean genotypic difference in growth, nutrient accumulation and ultrastructure in response to manganese and iron supply in solution culture. Ann. Bot., 96:149-158, 2005.

JOHNSON, C.M.; STOUT, P.R.; BROYER, T.C. \& CARLTON, A.B. Comparative chlorine requirements of different plants species. Plant Soil, 8:337-353, 1957.

KÜPPER, H.; ZHAO, F.J. \& MCGRATH, S.P. Cellular compartmentation of zinc in leaves of the hyperaccumulator Thlaspi caerulescens. Plant Physiol., 119:305-311, 1999

LAVRES JR., J. Influência genotípica na absorção, utilização e na toxidez de manganês na soja. Piracicaba, Universidade de São Paulo, 2007. 88p. (Tese de Doutorado) 
LAVRES JR., J.; MORAES, M.F.; CABRAL, C.P. \& MALAVOLTA, E. Influência genotípica na absorção e na toxidez de manganês em soja. R. Bras. Ci. Solo, 32:173$181,2008$.

LIDON, F.C. Rice plant structural changes by addition of excess manganese. J. Plant Nutr., 25:287-296, 2002.

LUFT, J.H. Improvements in epoxy resin embedding methods. J. Biophys. Biochem. Cytol., 9:409-414, 1961.

MALAVOLTA, E. Manual de nutrição mineral de plantas. São Paulo, Ceres, 2006. 631p.

MALAVOLTA, E.; VITTI, G.C. \& OLIVEIRA, S.A. Avaliação do estado nutricional das plantas: Princípios e aplicações. 2.ed. Piracicaba, POTAFOS, 1997. 319p.

MCQUATTIE, C.J. \& SCHIER, G.A. Response of sugar maple (Acer saccharum) seedlings to manganese. Can. J. For. Res., 30:456-467, 2000.

MORITA, A.; YOKOTA, H.; ISHKA, M.R. \& GHANATI, F. Changes in peroxidase activity and lignin content of cultured tea cells in response to excess manganese. Soil Sci. Plant Nutr., 52:26-31, 2006.

PAPADAKIS, I.E.; BOSABALIDIS, A.M.; SOTIROPOULOS, T.E. \& THERIOS, I.N. Leaf anatomy and chloroplast ultrastructure of Mn-deficient orange plants. Acta Physiol. Plant., 29:297-301, 2007a.

PAPADAKIS, I.E., GIANNAKOULA, A.; THERIOS, I.N.; BOSABALIDIS, A.M.; MOUSTAKAS, M. \& NASTOU, A. Mn-induced changes in leaf structure and chloroplast ultrastructure of Citrus volkamericana (L.) plants. J. Plant Physiol., 164:100-103, 2007b.

PITTMAN, J.K. Managing the manganese: Molecular mechanisms of manganese transport and homeostasis. New Phytol., 167:733-742, 2005.
RENGEL, Z. Physiological mechanisms underlying differential nutrient efficiency of crop genotypes. In: RENGEL, Z., ed. Mineral nutrition of crops: Fundamental mechanisms and implications. New York, Food Products Press, 1999. p.227-265.

REYNOLDS, E.S. The use of lead citrate at high $\mathrm{pH}$ as an electron opaque stain in electron microscopy. J. Cell Biol., 17:208-212, 1963.

ROSOLEM, C.A.; SACRAMENTO, L.V.S. \& OLIVEIRA, D.M.T. Kinetics of zinc uptake and anatomy of roots and leaves of coffee trees as affected by zinc nutrition. J. Plant Nutr., 28:2101-2112, 2005.

SANTANDREA, G.; SCHIFF, S. \& BENNICI, A. Effects of manganese on Nicotiana species cultivated in vitro and characterization of regenerated Mn-tolerant tobacco plants. Plant Sci., 132:71-82, 1998a.

SANTANDREA, G.; TANI, C. \& BENNICI, A. Cytological and ultrastructural response of Nicotiana tabacum L. roots to manganese stress. Plant Biosyst., 132:197-206, 1998b.

SAS Institute. SAS/STAT. User's guide, version 6.11. 4.ed. Cary, Statistical Analysis System Institute, 1996. v.2. 842p.

THOMPSON, I.A. \& HUBER, D.M. Manganese and plant disease. In: DATNOFF, L.E.; ELMER, W.H. \& HUBER, D.M., eds. Mineral nutrition and plant disease. Saint Paul, APS Press, 2007. p.139-153.

WEILAND, R.T.; NOBLE, R.D. \& CRANG, R.E. Photosynthetic and chloroplast ultrastructural consequences of manganese deficiency in soybean. Am. J. Bot., 62:501508,1975 .

YAN, S.L.; TSAY, C.C. \& CHEN, Y.R. Isolation and characterization of phytochelatin synthase in rice seedlings. Proc. Nat. Sci. Council, Part B, 24:202-207, 2000. 